\title{
The role of electronic management of human resources in psychological empowerment of human resources in Shiraz Gas Company
}

\author{
Asadallah Ganjali ${ }^{1}$, Raha Farhadi ${ }^{2}$, Mahdi Ahmadipanah ${ }^{3,{ }^{*}}$ \\ ${ }^{1}$ Assistant Professor, Department of Management, Imam Sadeq (AS) University, Tehran, IRAN \\ ${ }^{2}$ Phd student, Department of Management, Kharazmi University, Tehran, IRAN \\ ${ }^{3}$ Department of management, Payame Noor University, PO BOX 19395 - 3697, Tehran, IRAN \\ E-mail address: ma_ah_pa@yahoo.com
}

\begin{abstract}
Keywords: electronic management of human resources; psychological empowerment; Gas Company
\end{abstract}

\begin{abstract}
The main purpose of this research is investigation of the role of human resources electronic management in psychological empowerment of gas company employees in Shiraz. The present study is the descriptive research which was conducted by survey. The population of this research is the staff of Gas Company located in Shiraz. The considered population consisted 347 employees that 180 of them were selected and studied as a sample based on Morgan table. The instrument for gathering data in this research is questionnaires. For determining the validity of questionnaires, the content validity has been used. In addition, the masters' corrective comments have been applied. In this study, for investigating the reliability of instrument the Cronbach's alpha coefficients was used. The coefficient reliability of e-HR management questionnaires is 0/95 and the coefficient reliability of psychological HR questionnaires is $0 / 9$ which shows desirable reliability of this questionnaire. Results and findings of the research: the obtained results indicate that there is positive and direct relation between the two variables of electronic system for appointment and career path management and psychological empowerment of staff located in Shiraz Gas Company. And there is positive and direct relation between two variables of electronic system of payment based on performance and psychological empowerment of staff in Gas Company located in Shiraz. And the results show that between two variables of electronic system of education management and psychological empowerment of staff in Gas Company in Gas Company in Shiraz, there is a positive and direct relationship. There is a positive and direct relationship between two variables of electronic system of recruitment and election and psychological empowerment of staff in Shiraz Gas Company. Also, between two variables of electronic system of management performance and psychological empowerment of staff in Shiraz Gas Company there is a positive and direct relationship. Regarding the conducted survey, it is indicated that between demographic features (gender, age, education level, working experience and psychological empowerment) there is a significant differences.
\end{abstract}

\section{INTRODUCTION}

Iranian organizations have to face current challenges in the country as well as international trends and developments. On one hand, hierarchical organizational structures, low process of affairs, low productivity, unreal assessment of human resources and sometimes clients' or staffs' dissatisfaction and on the other hand developing document of twenty-year vision and announcing by the highest authority of the country oblige the authorities to provide situation that in a twenty year program starting in 1384, Iran becomes the first power of economical, technical, scientific in this region. Of course, achieving this goal will require extensive planning in various aspects that one of them will be the investigation of the country's administrative system and improvement of development indicators including improvement of HR management. 
Based on this, the policies promulgated by the supreme leader (including the provisions of 2 to 19 paragraphs), in $4^{\text {th }}$ chapter of the $5^{\text {th }}$ five-year program of Islamic republic of Iran and the $2^{\text {nd }}$ program of twenty- year outlook ( articles of 51, 50, 49,62) and regulations of staffs" "working far" or " work at home", pay attention to administrative and management issues. And the importance of e-government and other related requirements such as e-banking and e-HR management have been emphasized.

Regarding the international trend of development and using the information and communication technologies especially the internet and web technologies in doing the administrative activities and getting its benefit, in Iran regarding the fact that the official governmental organizations are dominant and decisive and 25 percents are allocated to employment, it is more than two decades that improvement of information and communication technology is on agenda of government and communication and specialized agencies. Due to effects of these strategies and its related actions, telecommunication and electronic technologies, computers and data transmission network, adequate growth and development have been done. Nearly a decade, a study, programming and actions for increasing the use of information communication technologies in different areas of education, research, culture, business, health care and management and planning based on international findings and experiences and national capacities with cooperation of government, private sector and scientific and social institutions have been followed.

Currently there are more than 32 million internet users in the country, but unfortunately in administrative system and HR management, these technologies are not used in improvement of organizations performance efficiently and effectively. Based on this, the main question is that in which circumstances Iranian organization can use information communication technologies in improvement of process and functions of management of their own HR? (Moosakhani et al, 2011).

The term electronic management of HR which has been used for the first time in 1990s refers to doing activities related to HR management by using web technologies. It seeks to provide information at any time or any place with managers, staff and consultant. Rapid development of internet during the last decade makes increase in its application and implementation. Moreover, the studies of HR consultants suggest that the number of both organization accepting e-management of human resource and soft ware relating to them are increasing continuously. Human resource management can be simultaneously more flexible, more cost-effective, and customer-oriented and be more strategic by using the web technologies. And it will be able to reduce management costs and increase productivity, short-faster response time, improve decision making and develop customer service ( Cedar, 2008).

Increasing and improving the administrative efficiency and using various technologies allow HR managers to use less personnel and play greater role and endogenous in their organizations. . Rapid development of systems providing electronic human resources services has caused to have information in a more suitable format and forms to the staff and managers. And they will be capable to take advantage of this information. In fact the electronic human resource management, E-HRM, by taking advantage of the advanced technologies and with a lot of utilities can be a supportive of human resource management. Human resources management includes strategic monitoring and managing the most valuable properties of organization which is those staff working in that organization and assist it to achieve its goal ( Darvish et al, 2010). On the other hand, in recent decades, The rapid spread of the Internet causes the e-HR to be strengthened, implemented and managed ( Lengnick-Hall \& Moritz, 2003).

\section{ASPECTS OF PSYCHOLOGICAL EMPOWERMENT}

\section{Sense of significance}

Being meaningful is an opportunity that people feel they are pursuing their important and valuable career goals, it means they feel they are moving in a path in which their time and energy is considered valuable. Meaningfulness is defined as the valuable career goals, and inner interest to 
careers. Meaningfulness refers to the balance between working requirements and beliefs, norms and behaviors. Regardless of organizational constraints, people tend to strive for goals that are meaningful to them (Greasly, 2004).

\section{Competency ( self- efficacy)}

'Competency' or 'self-efficacy', is the individual's belief in his/her capabilities and capacities for performing executive task. Actually, In fact, self-efficacy is a personal belief in changing their motivation, intuitive resources and a series of measures according to the requirements of a particular situation which can be considered as the opposite point of disability and incapability. In another word, competence refers to the degree to which an individual can perform a job with his/her abilities and low self-efficacy causes people who avoid situation that require appropriate skills ( Klidas, 2002).

\section{Sense of autonomy (self-determination)}

While the merit is a behavioral skill, the "autonomy" is a personal feeling about choice of step for regulating activity. Autonomy represents independency in step and continuous behaviors and processes. Feelings of autonomy is accompanied with less alienation in the workplace and higher job satisfaction and higher levels of job performance and greater entrepreneurial activity and higher levels of job involvement and less work pressure. From the perspective of management schools, freedom or self-determination should be tailored to the type of job and responsibility that a person is charged (Baild, 2006).

\section{Sense of effectiveness}

"Effective" refers to the extent to which the person is able to influence the outcomes of the strategic, administrative and operational outcome in their own jobs. Those people having strong aspect of effectiveness do not believe in limiting their abilities by external factors and believe that these factors can be controlled; the sense of 'active management' permits them to make the environment in line with their own desires. Unlike 'passive management' in which the people's desires are in accordance with the environment. Those having sense of effectiveness, strive to maintain dominance on themselves rather than reactive behavior to the environment.

\section{Self-confidence}

Talented people having a sense called "confidence" are sure that they will be treated fairly and equally. These people maintain this confidence that even in subordinate level; establish justice and peace in their final results. The meaning of this feeling usually is that they are sure the operators of authority or power cannot hurt or loss them, or they will not be treated impartially. Having the feeling that the behavior of others is stable and reliable and the information can be considered surely and that the promises will be done are all parts of formation of sense of empowerment (Gomez \& Rosen, 2001).

Despite the increasing development of e-HRM in organizations and the importance of psychological empowerment of human resources have in the survival of organizations, examining the review of literature show the research gap in the relation of electronic HR management on psychological empowerment of human resources.

The main purpose of this research is explanation of electronic HR management in psychological empowerment of human resources. Although it is logical to expect that activities of human resources management can affect each other significantly, so far there has been little evidence.

Although some of activities are consistent in this respect, as in (providing organizational support, careful play planning and system of performance management system), Critical requirements such as technology, strategy, and environment or life cycle are rarely taken into account when the details 
of these activities are examined. Therefore, the main issue of this research is the role of electronic human resources management in psychological empowerment oh human resources regarding Iran context and its organizations.

\section{METHODOLOGY}

Present study is the descriptive one which has been a survey one. The statistical population of this research is the staff of Gas Company located in Shiraz. The statistical population includes 347 employees that 180 ones were selected and investigated based on Morgan table. The instrument for gathering data in this research is questionnaire. For investigating electronic HR management with dimension of (The electronic system for appointments and career management path, the electronic payment system based on performance, electronic system of educational management, employment system and electronic election, electronic system of performance management and for examining the variable of psychological empowerment of human resources the standard Mishera and Spriitz with dimension of (competence, autonomy, effectiveness, being meaning meaningful, confidence) have been used.

For determining the validity of questionnaires, the content validity has been used. Corrective comments of masters have been applied. In this study, Cronbach's alpha coefficient was used to assess the reliability. The reliability coefficient of e-HR management questionnaire is $0 / 95$ and validity coefficient of psychological empowerment of HR questionnaire is $0 / 90$ which shows desirability of validity of questionnaires.

\section{Conceptual model}

Table number 1 shows the conceptual model of this research. The model has been driven from Sanayei and Mirzaei (2008) and presented the conceptual framework which can be found in Hayton (2005) called the relationship between human resource management and organizational entrepreneurship. In fact, it can be said that in today's organizations tasks and activities of human resource including staff and managers carried out through taking advantage of electronic human resource management subsystems will result in HR empowerment in organization. Accordingly, due to the conceptual model, the research questions were formulated as follows:

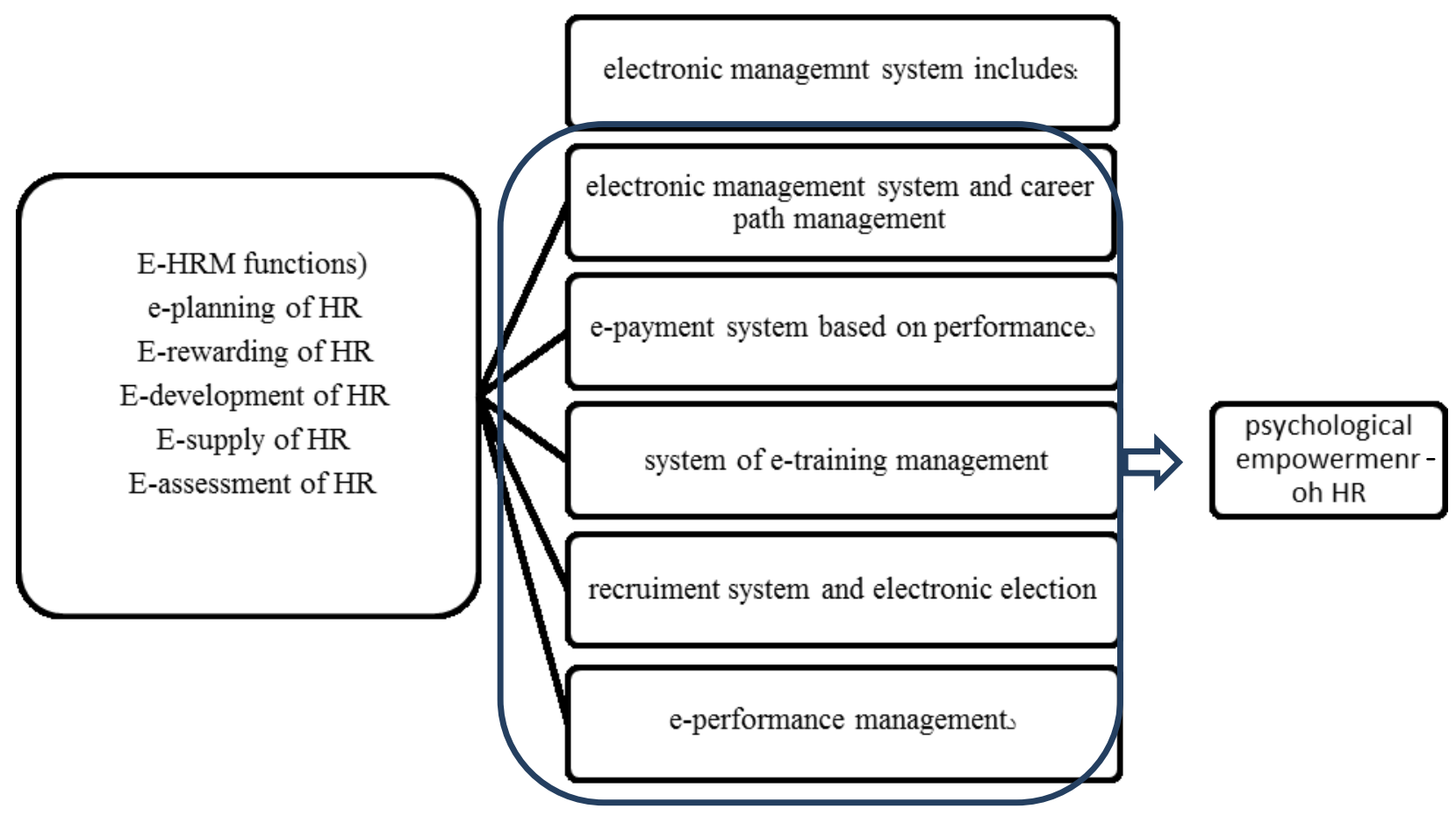

Figure 1. Shows the conceptual model from gotten from Hayton (2005) 


\section{Research questions}

1. Is there any relationship between electronic appointment system and career path management and psychological empowerment of HR in Gas Company?

2. Is there any relationship between electronic payment system based on psychological performance and empowerment of human resources in Gas Company?

3. Is there any relationship between the electronic training system of human resource and psychological empowerment in Gas Company?

4. Is there any relationship between the recruitment subsystem and electronic election and psychological empowerment, human resources in a gas company?

5. Is there any relationship between electronic system of management performance and psychological empowerment of human resources in gas company?

6. Is there any relationship between each of demographic features ( gender, educational level, working experience) and psychological empowerment of human resources in gas company?

\section{Research findings}

As previously stated, the purpose of this study is" investigation the role of electronic management of human resources in psychological empowerment of staff in gas Company located in Shiraz". For this purpose, 180 employees of this organization were selected and investigated as a sample, the following the results will be discussed. Information on the organization of cognitive staff is given in Table (1).

Table 1. Show demographic information of staff stationed in Shiraz Gas Company

\begin{tabular}{|c|c|c|c|c|c|c|c|c|c|c|c|}
\hline \multicolumn{3}{|c|}{ Educational level } & \multicolumn{3}{|c|}{ Job experience } & \multicolumn{3}{|l|}{ Age } & \multicolumn{3}{|l|}{ gender } \\
\hline percent & number & & percent & number & & percent & Number & & percent & number & \\
\hline $\begin{array}{l}7.2 \\
11.7 \\
48.9 \\
32.2\end{array}$ & $\begin{array}{l}13 \\
2 \\
88 \\
58\end{array}$ & $\begin{array}{l}\text { Diploma } \\
\text { under it } \\
\text { Associate } \\
\text { of arts } \\
\text { bachelor } \\
\text { Master } \\
\text { and } \\
\text { above }\end{array}$ & $\begin{array}{l}8.6 \\
17.7 \\
33.36 \\
12.22 \\
10 \\
11.7 \\
6.66\end{array}$ & $\begin{array}{l}15 \\
32 \\
60 \\
22 \\
18 \\
21 \\
12\end{array}$ & $\begin{array}{l}1-5 \\
\text { years } \\
5-10 \\
\text { years } 10 \\
10-15 \\
\text { years } \\
15-20 \\
\text { years } \\
20-25 \\
\text { years } \\
25-30 \\
\text { years } \\
30 \text { years } \\
\text { and } \\
\text { above }\end{array}$ & $\begin{array}{l}11.1 \\
58.9 \\
22.8 \\
7.2\end{array}$ & $\begin{array}{l}20 \\
106 \\
41 \\
13\end{array}$ & $\begin{array}{l}20-30 \\
\text { years } \\
30-40 \\
\text { years } \\
40-50 \\
\text { years } \\
50 \\
\text { years } \\
\text { old } \\
\text { and } \\
\text { above }\end{array}$ & $\begin{array}{l}81.1 \\
18.9\end{array}$ & $\begin{array}{l}146 \\
34\end{array}$ & $\begin{array}{l}\text { male } \\
\text { female }\end{array}$ \\
\hline
\end{tabular}

The results show that $81.1 \%$ of respondents were male (146) and $18.9 \%$ of female respondents (34). Distribution of respondents according to age as follows and indicated that most people are in the age group of 30-40 (58.9\%). Distribution of staff as well as the distribution of age, indicating that the force is young and more employees in the category of 10 to 15 years $(33.36 \%)$ have work experience. In the considered organizational, most people have a bachelor's degree (48.9\%).

1. Is there any relationship between electronic system of appointment and career path management and psychological empowerment of human resource in Gas Company? 
For examining the relationship between the electronic system of appointments and career management and psychological empowerment of human resources of gas company correlation Pearson has been used that its results are presented in table (2).

Table 2. Show electronic appointment system and career path management and psychological empowerment of HR

\begin{tabular}{|l|l|l|l|}
\hline $\begin{array}{l}\text { Significant } \\
\text { level }\end{array}$ & Correlation & Variables \\
\hline $0 / 000$ & $0 / 551$ & $\begin{array}{l}\text { electronic appointment system and career path } \\
\text { management and psychological empowerment }\end{array}$ \\
\hline
\end{tabular}

As it has been observed in table (2), a direct and significant relation can be found between electronic system of appointment and career management and psychological empowerment of staff in gas company located in Shiraz $(\mathrm{r}=0 / 551)$. This relationship is significant at alpha level of 0.00 .

2. Is there any relationship between E-payment system based on performance and psychological empowerment of human resource in Gas Company?

For examining the relationship between e-payment system based on performance and psychological empowerment of human resource, a Pearson correlation has been used that its results can be presented in table3.

Table 3. E-payment subsystem based on performance and psychological empowerment of human resource

\begin{tabular}{|l|l|l|l|}
\hline $\begin{array}{l}\text { Significant } \\
\text { level }\end{array}$ & Correlation & Variables \\
\hline $0 / 000$ & $0 / 631$ & $\begin{array}{l}\text { : E-payment subsystem based on performance and } \\
\text { psychological empowerment of }\end{array}$ \\
\hline
\end{tabular}

As it has been observed in table (3), a direct and significant relation can be found between two variables of e-payment system based on performance and psychological empowerment of staff in gas station located in Shiraz $(\mathrm{r}=0 / 631)$ that this relationship is significant at alpha level of 0.00

3. Is there any relationship between E-training management system and psychological empowerment of human resources in Gas Company?

A correlation Pearson has been used for examining the relationship between e-learning management and psychological empowerment of human resources in Gas Company. The results have been shown in table number 4.

Table 4. E-training management system and psychological empowerment of human resources in Gas Company

\begin{tabular}{|l|l|l|}
\hline $\begin{array}{l}\text { Significant } \\
\text { level }\end{array}$ & correlation & Variables \\
\hline $0 / 000$ & $0 / 562$ & $\begin{array}{l}\text { E-training management system and psychological } \\
\text { empowerment of human resources in gas company }\end{array}$ \\
\hline
\end{tabular}

As it has been observed in table (4), between two variables of e-learning management and psychological empowerment of staff in Gas Company located in Shiraz a significant and direct relation can be observed( $\mathrm{r}=0 / 562)$. this relationship is significant at alpha level of 0.00 . 
4. Is there any relationship between recruitment system and electronic election and psychological empowerment of human resource in gas company?

For examining the relation between relationship between recruitment system and electronic election and psychological empowerment of human resource in Gas Company, a correlation Pearson has been used. In table number 5 their results are presented.

Table 5. Recruitment system and electronic election and psychological empowerment of human resource in Gas Company

\begin{tabular}{|l|l|l|}
\hline $\begin{array}{l}\text { Significant } \\
\text { level }\end{array}$ & correlation & Variables \\
\hline $0 / 000$ & $0 / 533$ & $\begin{array}{l}\text { recruitment sub-system and electronic election and } \\
\text { psychological empowerment of human resource in } \\
\text { gas company }\end{array}$ \\
\hline
\end{tabular}

As it has been observed in table (5), a direct and significant relationship can be found between two variables of electronic election and recruitment system and psychological empowerment of staff in gas company located in Shiraz $(\mathrm{r}=0 / 533)$. This relationship is significant at alpha level of 0.00 .

5. Is there any relation between electronic system of management performance and psychological empowerment of human resource in Gas Company?

To study the relationship between the electronic system of performance management and psychological empowerment of human resource in Gas Company, a correlation Pearson has been used.

Table 6. Electronic system of performance management and psychological empowerment of human resource in Gas Company

\begin{tabular}{|l|l|l|}
\hline $\begin{array}{l}\text { Significant } \\
\text { level }\end{array}$ & correlation & Variables \\
\hline $0 / 000$ & $0 / 631$ & $\begin{array}{l}\text { electronic system of performance management and } \\
\text { psychological empowerment of human resource }\end{array}$ \\
\hline
\end{tabular}

As it has been observed in table (6), between two variables of electronic system of performance management and psychological empowerment of staff in gas company located in Shiraz, a direct and significant relation can be found( $\mathrm{r}=0 / 631)$.this relation is significant at alpha level of $0 / 00$.

Is there any relationship between each of demographic features (gender, age, educational level, work experience) and psychological empowerment of human resources in Gas Company?

Table 7. Correlation between of demographic features (gender, age, educational level, work experience) and psychological empowerment

\begin{tabular}{|c|c|c|c|}
\hline $\begin{array}{l}\text { Significant } \\
\text { level }\end{array}$ & $\begin{array}{l}\text { Correlation } \\
\text { level }\end{array}$ & $\begin{array}{ll}\text { Type } & \text { of } \\
\text { correlation }\end{array}$ & Variables \\
\hline $0 / 005$ & $-0 / 206$ & pearson & $\begin{array}{l}\text { Gender and psychological } \\
\text { empowerment }\end{array}$ \\
\hline $0 / 134$ & $0 / 112$ & pearson & $\begin{array}{l}\text { Age and psychological } \\
\text { empowerment }\end{array}$ \\
\hline $0 / 000$ & $-0 / 295$ & pearson & $\begin{array}{lll}\text { Educational level } & \text { and } \\
\text { psychological empowerment } & \\
\end{array}$ \\
\hline $0 / 212$ & $0 / 94$ & Pearson & $\begin{array}{ll}\text { Working experience } & \text { and } \\
\text { psychological empowerment } & \end{array}$ \\
\hline
\end{tabular}


According to the survey it has been indicated that between gender and psychological empowerment $(005 / 0=r)$ there is a significant difference. It means the employees' gender in Gas Company located in Shiraz affect their psychological empowerment. The level of psychological empowerment in men and women employing in Gas Company are different.

Based on the obtained results, there is a significant relationship between age and psychological empowerment $(\mathrm{r}=0 / 134)$. It means the employees' age in Gas Company located in Shiraz affect their level of psychological empowerment.

Based on some investigations, it has been clear that between level of educational level and psychological empowerment a significant difference can be found. In another words, the employees' educational level in Gas Company affects the psychological empowerment. The results indicate there is a significant relationship between working experience and psychological empowerment (0/122). It means if the working experience of employees in Gas Company increase, their level of psychological employment will increase too.

\section{CONCLUSION}

The purpose of conducting this study is "investigation the role of electronic management of human resources in psychological empowerment of employees in Gas Company located in Shiraz". For this purpose, 180 people working in Gas Company located in Shiraz were investigated by simple random sampling. The obtained results regarding two variables of e-appointment system and career management and psychological empowerment of staff in Shiraz Gas Company indicate that there is a direct and significant relation between these two variables $(\mathrm{r}=0.551)$, and between two variables of e-payment system based on performance and psychological empowerment of employees in shiraz gas company there is a positive and direct relationship $(\mathrm{r}=0 / 631)$. This relation is significant at alpha level of $0 / 00$.

Moreover, the results show that the variable of e-learning of management system and variable of psychological empowerment of staff in gas company located in Shiraz, a direct and significant relation can be found $(\mathrm{r}=0 / 562)$. Also between two variables of recruitment system and electronic election and psychological empowerment, there is a direct and significant relationship. This association is meaningful at alpha level of $0 / 00$.

A correlation Pearson has been used for examining the electronic system of management performance and psychological empowerment of employees in Gas Company. The results indicate that between electronic system of management performance and psychological empowerment of staff in gas company, a direct and significant relation can be found $(\mathrm{r}=0 / 631)$. This relation is meaningful at alpha level of $0 / 00$. According to some investigation, it has been obvious a significant difference is between genders and psychological empowerment $(\mathrm{r}=0 / 005)$. In another words, the employees' genders in Shiraz Gas Company affect their psychological empowerment. The level of psychological empowerment between two genders of men and women is different. The results represent that a significant difference between genders and psychological empowerment $(\mathrm{r}=0 / 134)$ can be found. It means the employees' age in Shiraz Gas Company affect their psychological empowerment. Regarding some examination, between educational level and psychological empowerment $(\mathrm{r}=0 / 000)$ a meaningful difference can be found. In another words, the educational level is effective on level of psychological empowerment of employees' in Shiraz gas company. The findings show there is a significant difference between the staff working experience and their psychological empowerment. It can be said that if the employees' job experience increases, the level of their psychological empowerment will increase too. So it can be added that, the management and optimization of human resources in an organization can play an important role in enhancing the capabilities of its staff. The psychological empowerment means a sense of competence, autonomy and a sense of satisfaction and trust of the employees in an organization. Thus how managers largely determine the health of an organization and its staff's performance and 
yields. So all of the organizations need to pay attention to systems management of all subsystems including management system training, recruitment, and performance in order to deliver first word in today's competitive world.

\section{References}

[1] Moosakhani, M., Maniyan, A., Hassangholi poor, T., Mirbaha, O., \& Abtin, A. (2011). Presenting a model for electronic management of human resources in state organization in Iran. studies of general research, 4(14): 41-62.

[2] Baild, J. (2006). "The Intent Leave: An Investigation of Empowerment Mechanism, job satisfaction, and organizational commitment Among Technical College Employees". Unpublished dissertation. Cappella University.

[3] Cedar, C. (2008). CedarCrestone 2007-2008 HR systems survey HR technologies, service delivery approaches, and metrics. Available at: www.cedarcrestone.com/research.php. Retrieved July.

[4] Darvish, H., Karim Zadegan, D., \& Mirzanezhad, R. (2010). E-readiness Assessment Organization for Establishment Electronic Human Resource Management Systems (Case study Company saipa). Proceeding of the First Annual Conference on Management, Innovation and Entrepreneurship: Shiraz.

[5] Gomez, C. \& Rosen, B (2001). "The leaded- member Exchange as a link between managerial trust and employee. Empowerment. Group and organization management".

[6] Greasly, K. (2004). "Employee participation of empowerment". Employee Relation, 27(4): 354-368.

[7] Hayton, J. C. (2005). Promoting corporate entrepreneurship through human resource management practices : A review of empirical research. Human Resource Management Journal, 15(5): 21-41.

[8] Sanayei, A., \& Mirzaei, A. (2008). Designing a model for evaluating the effectiveness of e-hrm (Case Study: Iran ian organizations). International Journal of Information Science and Management; 6(2): 79-98.

[9] Klidas, A. K. (2002). "Employee empowerment in the European cultural context: findings from industry". PhD, thesis, Amsterdam: Rozenberg Publishers.

[10]Lengnick-Hall, M., \& Moritz, S. (2003). The impact of e-HR on the human resource management function. Journal of Labo Research. 24(3): 365-80. 